\title{
Rainwater management role to solve problem related to hydro- environment engineering
}

\author{
Susilawati Cicilia Laurentia ${ }^{1, *}$, Yulius PK Suni², and Alfred Fredrich Lukas ${ }^{3}$ \\ ${ }^{1}$ Civil Engineering Study Program, Faculty of Engineering, Flores University, Ende, Indonesia \\ ${ }^{2}$ Institute of Resource Governance and Social Change, Kupang, Indonesia \\ ${ }^{3}$ Balai Wilayah Sungai Nusa Tenggara II, Directorate General of Water Resources, Ministry of Public Works and Housing, Kupang, \\ Indonesia
}

\begin{abstract}
The problems related to hydro-environmental engineering on small islands are flood and drought, for the less favourable rainfall characteristics. Big rainfall intensity comes and flows immediately as storm runoff to the sea because of short distance, and no chance to infiltrate into the soil as ground-water recharge. Floods and landslides occur during rainy season and drought during the dry season. This research investigates the role of rainwater management in order to overcome these problems. The literature review and field observations of experiences on rainwater management techniques applied on both communal scale and household level. The results show that firstly, rainwater must be managed in ways that small amount of rainwater flows out immediately to the sea. So, it has the chance to infiltrate into the soil as ground-water recharge. This is done by making some water-traps series, harvesting rainwater and storing it into the ponds at the household scale. The water then could be utilized for domestic and agriculture purposes. Secondly, learning from several experiences' technology implementation as water conservation, it can be found the right way to manage rainwater at communal/household scale. These actions give the rainwater management having contributions to solve problems related to hydroenvironments engineering.
\end{abstract}

\section{Introduction}

The problems related to hydro-environmental engineering on small islands are flood and drought, for the rainfall characteristics are less favourable. Big rainfall intensity comes and then flows immediately as storm runoff to the sea because of short distance on small islands. Small islands have special characteristic associated with their small size, insularity, remoteness, and proneness to natural disasters (Figure 1) [1].

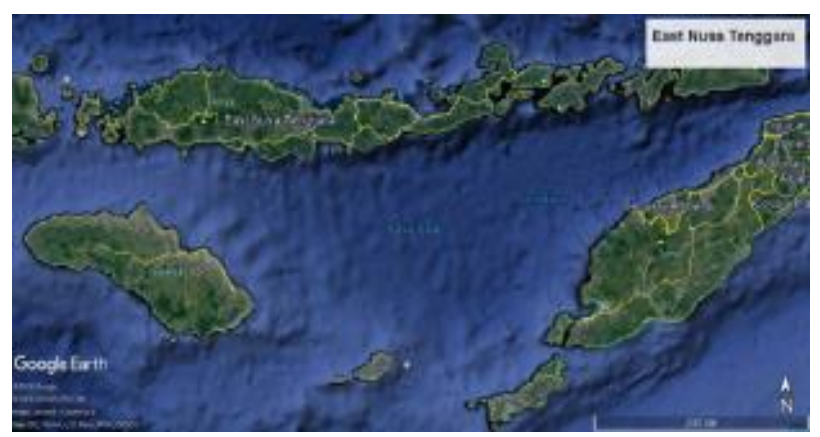

Fig. 1. Small islands of East Nusa Tenggara [2]

Such as on the Flores islands with less favourable distribution of rainfall (Table 1), resulted dry-spell and waterlogging condition in the rainy season. This condition caused the collapse of agriculture production, especially for rainfed agriculture.

Table 1. The potential dry-spell and waterlogging condition in the rainy season

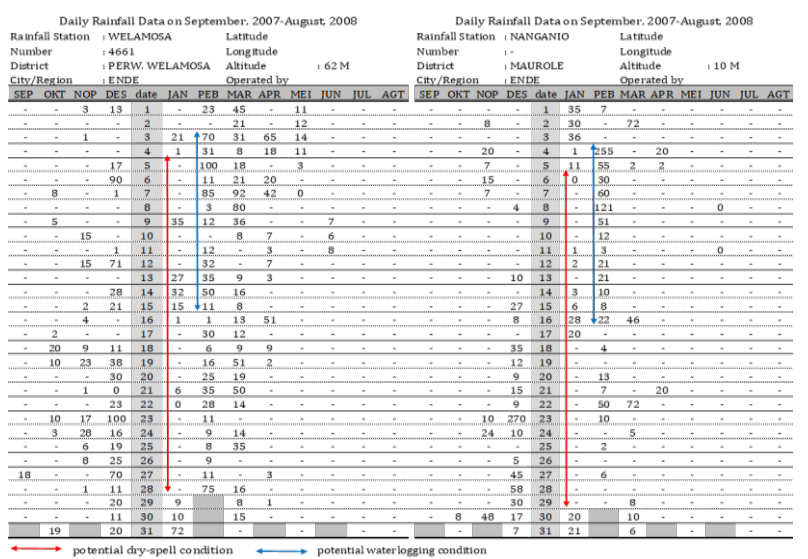

Source: Welamosa rainfall station [3]

The farmer in Flores started planting the crops in the mid of December 2007 after having few days of rainfall. Unfortunately, there was no rain for almost than 3 weeks. This condition made some crops fail to grow (dry spell).

\footnotetext{
* Corresponding author: $\underline{\text { sr.susi.dp@gmail.com }}$
} 
The survival crops faced heavy rainfall for 2 weeks in early February 2008 which in turn made the crops getting rotten.

Figure 2 provides diurnal variation of the mean enhancement is plotted as a function of local time in the Indo-Pacific region [4].
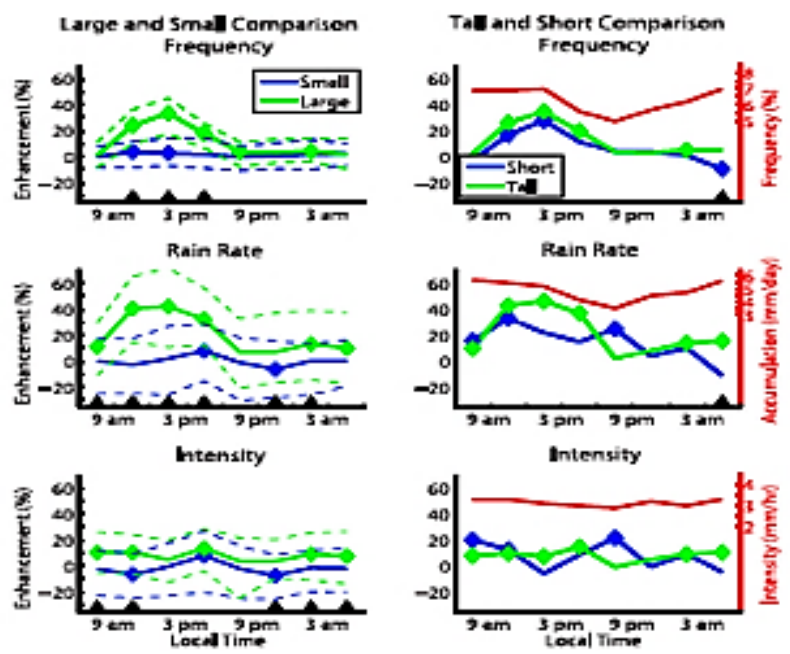

Fig. 2. Diurnal variation of the mean enhancement is plotted as a function of local time in the Indo-Pacific region [4]

On the left are the 3-hourly mean enhancements for islands greater than (green line) and less than (blue line) $315 \mathrm{~km}^{2}$. Dashed lines plot the $25^{\text {th }}$ and $75^{\text {th }}$ percentiles of the distribution of enhancements. (right) Mean enhancements are plotted for islands with a $75^{\text {th }}$ percentile elevation value greater than (green line) and less than (blue line) $50 \mathrm{~m}$, with only islands with area greater than $315 \mathrm{~km}^{2}$ used in the calculation. A solid diamond symbol is used to indicate when a particular value is significantly different than zero. A solid black triangle on the $\mathrm{x}$ axis is indicative of a significant positive difference between the large and small or tall and short islands. (right) A red line is used to plot the mean value of each variable averaged over all oceanic points surrounding the islands, used as a reference to the relative enhancements given [4].

Triggered by the rainfall characteristics in those areas, which are less favourable, then the problem increasing becomes more severe disaster, such as drought and flood, which cannot be separated. That is happened because of great intensity rains comes, then runoff water immediately flows directly through the river or natural drainage as heavily run off to the sea, because of the short distance/small size of small islands. As a result, there is no rainfall water have chance to infiltrate to the soil as a ground water recharge. Then flood disasters occur during the rainy season and drought during the dry season. Managing rainwater is an action to direct the runoff flow to be harvested and collected or conserved in accordance to the needs, and use it to meet the requirement. This needs a research on the role of rainwater management in order to overcome these problems.

By the simple conservation concept: rainfalls are the main water free of charge asset, so it has to manage well by developing the local wisdom concept exist, as watertrap series. No or very small magnitude rainfall water on the areas, will be just go away and flow quickly to the sea.
So that flood problems can be overcome, as well as drought. Further rain water management will also play an important role in overcoming the problems related to environmental water engineering, namely in providing sustainable water availability for domestic, municipal and agriculture requirement.

\section{Research study}

Managing rainwater can be done on a watershed, such as reservoirs or dams and a smaller scale, namely subwatershed, such as water-trap series along the gully natural drainage [5]. It has been developed to manage the rainwater on a smaller scale as household scale [6] and at home.

Based on the principle that rainfall water which fallen in the home-yard are the main water free of charge asset, so that will not be allowed to flow out from the owner's yard. It has been developed to manage rainwater on household scale for home-yard agriculture and cleanwater with mineralization process. The structures were constructed, operated and maintenance by the family themselves. This case initiates further to develop community-based motion for managing rainwater on household scale as the motion for rainwater management in household to improve water resilience in a changing world.

The water-trap series are intended to manage the flowing of the rainfall water through the river or natural drainage, as water conservation approach. The puddles happen gives the opportunity for the water to infiltrate into the soil as groundwater recharge (Figure 3).

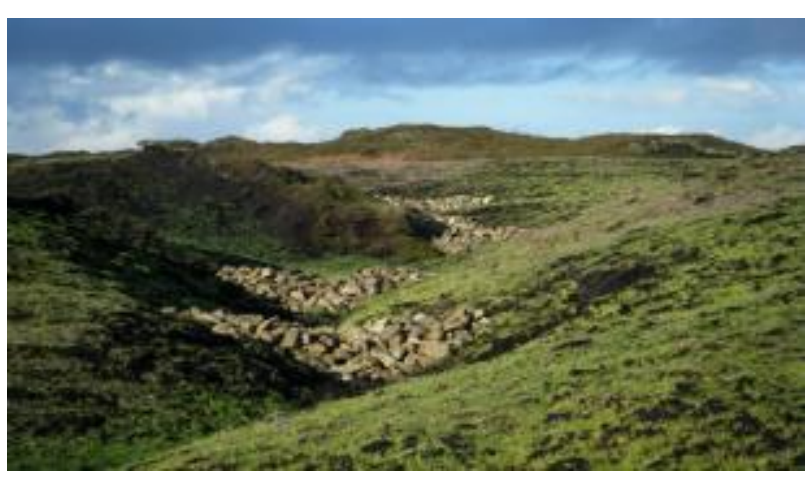

Fig. 3. Water-trap series construction

The concept of water-trap series on natural gully is to trap runoff flow with series of small dam. These traps will hamper the runoff flow, so have sufficient time to infiltrate to the soil and maintains the ground water surface. These traps like small dams developed from local wisdom and can be built by people participation, which guarantee the sustainability of the system, especially in operational, management and maintenance. Actually, this concept looks like as artificial recharge of aquifer concept, which based on the water balance at surface and within the groundwater system, as ecological rainwater management.

Ecological rainwater management methods in urban areas can contribute to [7]:

1. Reduction of total rainwater runoff and of its peak 
2. Storage of rainwater, in order to cover low quality water demand, such as household field irrigation.

3. Storage of rainwater (with mineralization process) also can be used for domestic or drinking after cooked first.

4. Local aquifer replenishment.

5. Reduction of property damage and activity disruption, which is due to insufficient sewer networks

6. Improvement of rain runoff quality through pollutant retention, filtration, decomposition, plant uptake, etc.

7. Mitigation of pollution of runoff receiving water bodies and

8. Upgrading of urban and suburban landscape

The main problem in rural areas is impermeable surfaces (e.g. caused by roads and buildings) and overstrained sewer systems. In rural areas and agricultural land, it can lead to erosion. Furthermore, this water could be used for agriculture and drinking water (Figure 4).

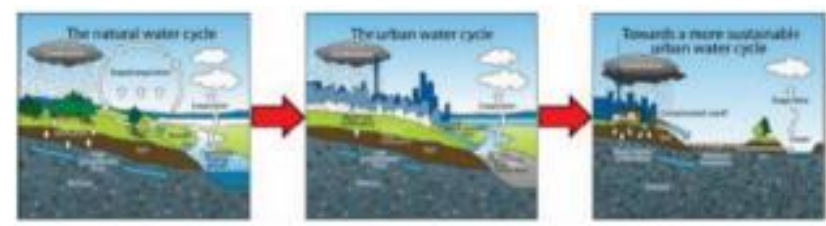

Fig. 4. Storm-water management in urban areas. From left to right: a natural water cycle allows infiltration, groundwater flow and evapotranspiration. When urban areas seal surfaces and avoid groundwater recharge or infiltration, floods occur. Modern techniques use natural processes (e.g. infiltration ponds or wetlands) to manage runoff water. Source: Auckland City Council, 2010 [8].

John Freeborn [9], wrote that practices to minimize runoff or improve infiltration storm-water on residential sites can be dealt with in a number of ways. The following techniques, which can be integrated into new construction and existing residential settings, help to manage stormwater: 1) Increasing permeability, 2) Directing water to more permeable areas, 3) Detaining water to allow infiltration, 4) Intercepting and holding rainwater and 5) Utilizing water on-site as it is needed.

The rainwater that falls on the field yard is captured and directed to flow into the rainwater catcher gutter, which is equipped with a mix of rock, sand and fibres to manipulate the mineralization process, so previous research implementation/application some new experiences emerging new ideas literature study new concept/theoretical paper that the water quality is increased. Similarly, rainwater that falls on the roof top of the house is directed to flow into the rainwater catcher gutter to be collected into rainwater ponds/wells that have undergone a process of mineralization. Overflow can be channelled into a bio-retention area such as a rain garden or swale. Two kind of ponds/wells storage can be used as domestic needs (with mineralization process) and irrigation water for household agriculture (without mineralization process). This action can be done in small scale or more. By the simple conservation concept, that rainfalls are the main water free of charge asset, so it has to manage well by developing the local wisdom concept exist. No or very small magnitude rainfall water on the areas, will be just go away and flow quickly to the sea (Figure 5).

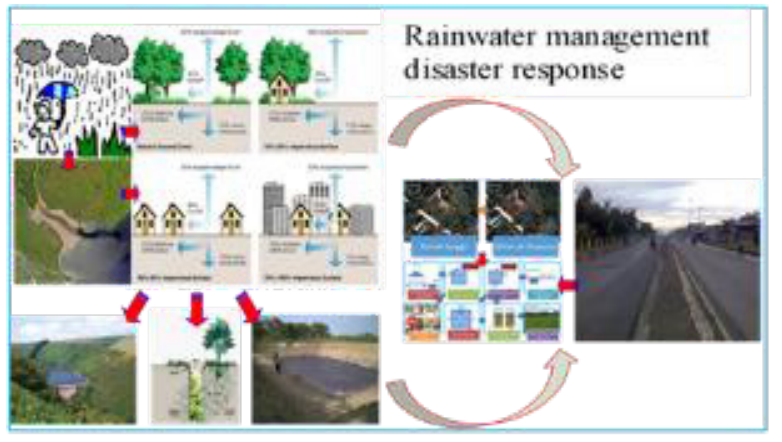

Fig. 5. Rainwater management in various disaster responses

Further, rain water management will also play an important role in overcoming the problems related to environmental water engineering, namely in providing sustainable water availability for domestic, municipal and agriculture requirement (Figure 6).

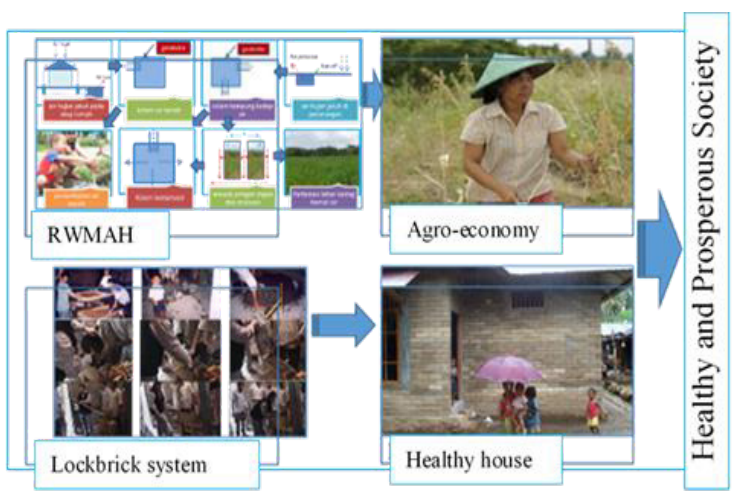

Fig. 6. Integration between lock-brick system and rainwater management

The available water can be used for everything, especially also for supporting forestation, which will be able to restore the hydro-environment to get better. The combination of planting seasonal trees into digging planting holes, where each plant needs a deep hole that is partially covered with soil, allowing water to be trapped in the planting hole [10]. This will make the rainwater runoff infiltrating into the soil. This concept could conserve the water as well.

\section{Methodology}

The methodology of the study is described in Figure 7.

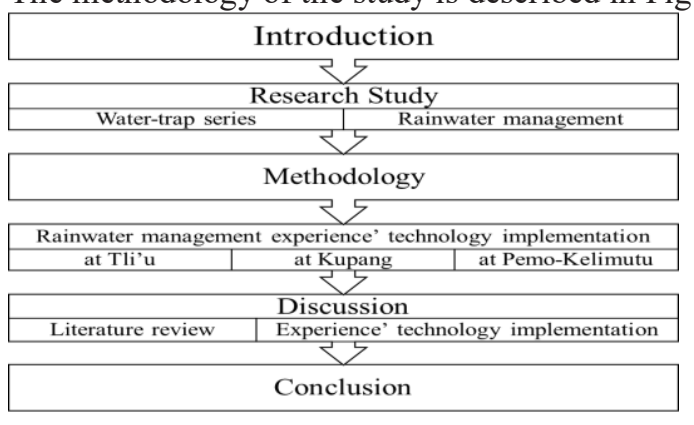

Fig. 7. The methodology of the study 
Firstly, the study identified the small island characteristic and problem related rainwater. This study consists of the literature review related to the water-trap series and rainwater management concept. Secondly, by learning from several experiences of rainwater management, it can be found the right way in managing rainwater of communal or household scale. The study ended with conclusion.

\section{Rainwater management experiences' technology implementation}

\subsection{Rainwater management in household scale technology implementation}

Rainwater management construction in household scale was implemented at Tli'u village, East Amanuban District, South Central Timor Regency, East Nusa Tenggara Province, Indonesia. The construction was done in 2015. First, the research conducted an investigation of runoff flow direction over the land. From this investigation result, could be determined the rainwater tank location and layout of rainwater channel catcher as mineralization process for clean water tank. This is shown in the Figure 8, 9 and 10.

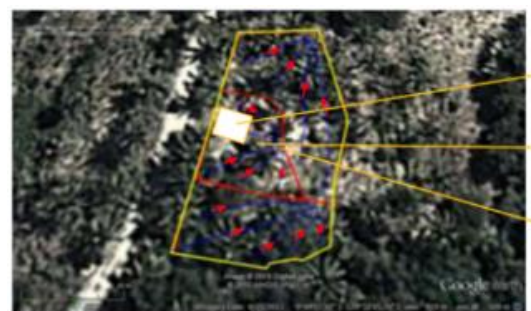

Lockbrick house

The existing house

Ferro-cement pond

Fig. 8. The situation of rainwater management construction in household scale
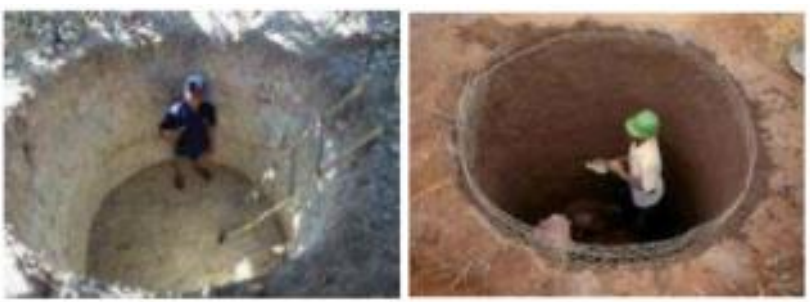

Fig. 9. The rainwater tank made from ferro-cement.
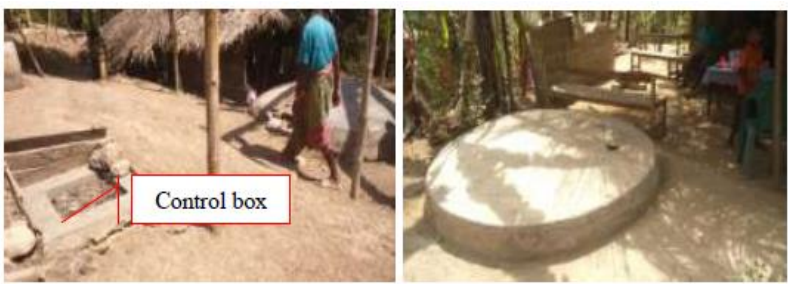

Fig. 10. Control box from mineralization process for clean water tank

This experience' technology implementation had good result in coping with the clean water problem, for agriculture and domestic requirement, during 8 months dry seasons, by 3 ferro-cement tanks.

\subsection{Rainwater management construction in Nasipanaf, Kupang Regency dormitory}

Rainwater management system was constructed in integration with the construction of student dormitory in Nasipanaf, Kupang Regency. This rainwater management system was designed to meet the water requirement for dormitory residents. The infrastructure consists of a rainwater reservoir, which received water from the catching channels of rainwater runoff. This is shown as in the Figure 11.

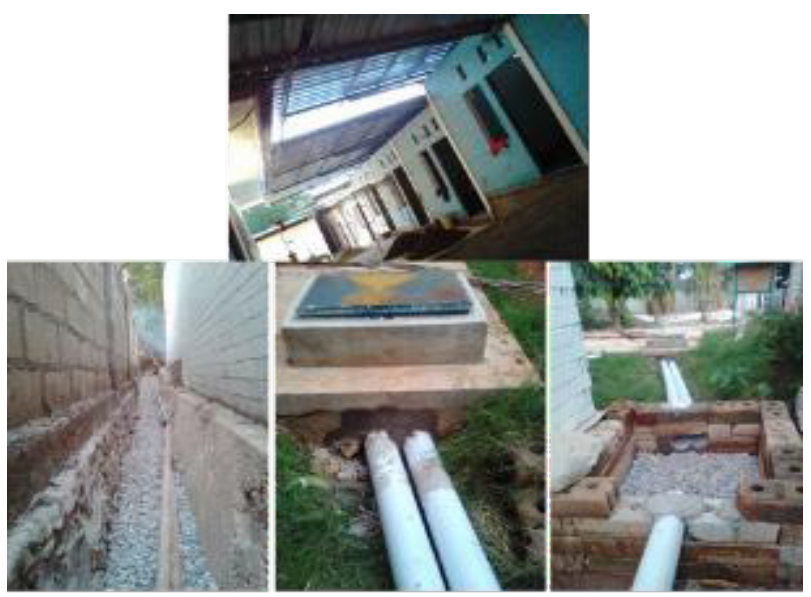

Fig. 11. Rainwater management construction in Nasipanaf, Kupang Regency dormitory

This experience' technology implementation had given the clean water requirement for 15 students' dormitory. Infrastructures are two reservoirs of $40 \mathrm{~m}^{3}$ and $90 \mathrm{~m}^{3}$.

\subsection{Rainwater management construction in Pemo village Moni-Kelimutu}

This experience' technology implementation still under construction. The rainwater management system was constructed in integration with the home-stay to support Kelimutu tourism. Figure 12 describe the construction of reservoir to accommodate rainwater management from the channel. The construction of reservoir is under the ground near the home-stay for tourism which works also as retaining wall for one side of reservoir.
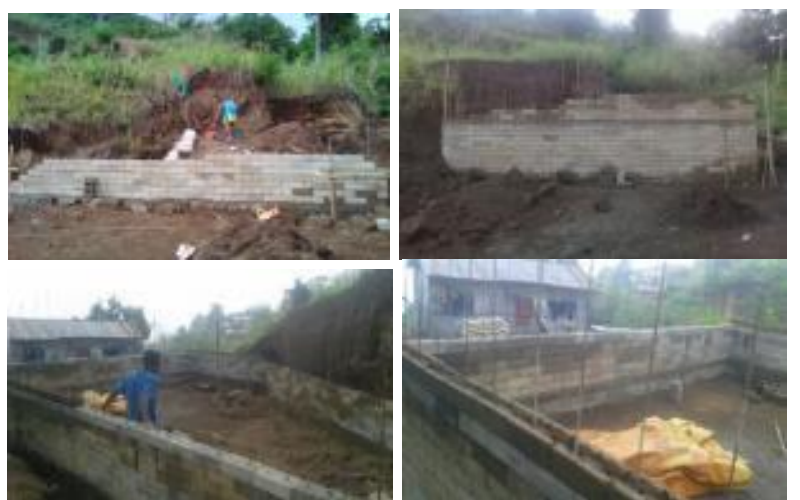

Fig. 12. The construction of reservoir below the home-stay for tourism 
This experience' technology implementation will give the clean water for domestic and vegetables yard requirement in order to support the small restaurant in this area.

These experiences' technology implementation are rainwater management in small scale. This give the good result in coping the water requirement. This technology also can build by people themselves because of the simple technology in construction. People themselves also responsible for operational and maintenance cost.

\section{Discussion}

International River Network and twelve other organizations [11], published twelve reasons to exclude large hydro from renewables initiatives. A major expansion of large hydro will harm sustainable development

1. Large hydro does not have the poverty reduction benefits of decentralized renewables

2. Including large hydro in renewables initiatives would crowd out funds for new renewables

3. Promoters of large hydro regularly underestimate costs and exaggerate benefits

4. Large hydro will increase vulnerability to climate change

5. There is no technology transfer benefit from large hydro

A major expansion of large hydro will harm people and ecosystems

6. Large hydro projects have major negative social and ecological impacts

7. Efforts to mitigate the impacts of large hydro typically fail

8. Most large hydro developers and funders oppose measures to prevent the construction of destructive projects

9. Large reservoirs can emit significant amounts of greenhouse gases. A major expansion of large hydro will harm energy security

10. Large hydro is slow, lumpy, inflexible and getting more expensive

11. Many countries are already overdependent on hydropower

12. Large hydro reservoirs are often rendered nonrenewable by sedimentation

Every hydro plant is unique in its design, location and impacts. While there is no directly proportional relationship between the installed capacity of a hydro plant and its impacts, in general one can expect higher impacts as the size of the project increases. Small hydro can, if responsibly implemented, be environmentally and socially low-impact and provide many of the benefits of new renewables, in particular providing power and related development benefits to dispersed rural communities. If badly implemented, however, without regard to community needs or its impacts on rivers and streams, small hydro can replicate many of the negative consequences of larger schemes. The cumulative impacts of multiple small hydro schemes on.
A note on global dam statistics [11], that no estimates have been done for the cumulative impacts of the world's large hydro projects, although estimates are available for the global impacts of the world's large dams. While large and small hydro are defined according to their generating capacity, large and small dams are defined according to their physical size. The key criterion for a large dam is that it is at least 15 meters high. The great majority of large hydro plants include a large dam - but the great majority of large dams were built for purposes other than electricity generation so are not hydro projects.

According to dam-industry statistics used by the World Commission on Dams, around 5,300 (11\%) of the world's 48,000 large dams were built solely for hydropower. A further $13,300(28 \%)$ were built for more than one function. Many of these multipurpose dams, especially the larger ones, have a hydropower function although the exact percentage has not been calculated. Hydropower is almost always a component of the biggest dams that have displaced the most people and have the greatest environmental impacts.

Research has shown that trees can play a substantial role in reducing storm-water runoff via canopy interception loss, transpiration, facilitating infiltration, and by coupling trees with other green infrastructure technologies such as bio-swales and structural soils [12].

\section{Conclusion}

From several research studies and the experiences' implementation of rainwater management systems, as well as environmental impact studies of a large dam and some small reservoirs provided by IRN, it can be concluded that the rainwater management could change the hydro-environment if these small islands have many trees and plants.

Gratitude expression was addressed to the NGO "Yayasan Tangan Pengharapan", which has helped in the implementation of rainwater management in household scale concept, at the home-yard of Mr. Lukas Hiler Liunesi, Tli'u village, East Amanuban district, South-Central-Timor regency and the Flores Higher Education Foundation, which provides widespread opportunities in the development of an integration of rainwater management systems and lockbricks to serve wider community

\section{References}

1. Asian Development Bank. Maldives: Overcoming the Challenges of a Small Island State Mandaluyong City, Philippines, (2015) Download at: https://www.adb.org/sites/.../maldives-overcomingchallenges-small-island-state.pdf

2. Google Earth, East Nusa Tenggara Map, (2018)

3. BMKG. Daily Rainfall Data of Welamosa Station, September, 2007 - August 2008, (2017)

4. Sobel, et.al. Rain on small tropical islands. Journal of Geophysical Research, Vol. 116, D08 102, doi:10.1029/2010JD014695, (2011)

5. Susilawati. Pengelolaan Air Hujan untuk Pertanian Pada Pulau Kecil di Kawasan Kering Indonesia. Gita Kasih - ISBN 978-979-3748-89-4, Kupang, (2011) 
6. Susilawati. Peran Inovasi Pengelolaan Air Hujan Skala Rumah Tangga Menuju Infrastruktur Tanggap Bencana Banjir dan Kekeringan yang Efektif, Efisien dan Berkelanjutan. Prosiding KoNTekS 9, Paper ID: INF04 Hal.27-31, (2015)

7. Papafotiou and Katsifarakis. Ecological Rainwater Management in Urban Areas. Preliminary Considerations for the city of Corinth, Greece. Agriculture and Agricultural Science Procedia, 4 (2015) 383 - 391. Download at: http://ac.elscdn.com/S2210784315001060/1-s2.0-S2210784315 001060main.pdf? tid=a41eeaf4-2d34-11e6-b15d 00000aacb362\&acdnat $=1465361659$ 8b994577116 8db070863d91afac4792b

8. Beat Stauffer (seecon international gmbh). Stormwater Management. Compiled by: Beat Stauffer, (2012) download at: http://archive.sswm.info/print/2024?tid=2650

9. J. Freeborn, et.al. Decreasing Runoff and Increasing Storm-water Infiltration. Journal of Green Building Vol 12 Issues 4, (2017) Download at https://pubs.ext.vt.edu/content/dam/pubs_ext_vt_ed u/426/426-046/426-046-PDF.pdf

10. A. Mahyudi, I. Al zaqie, and Tim Reforestasi KFCP. Panduan Penanaman Pohon Program Reforestasi (Kalimantan Forests and Climate Partnership$K F C P$ ). Download at: http://www.fordamof.org/files/18. Panduan Penanaman Pohon Pro gram_Reforestasi.pdf

11. International Rivers Network (IRN). Twelve Reasons to Exclude Large Hydro from Renewables Initiatives, (2003). Download at: www.rivernet.org/ general/hydropower/12reasons.pdf

12. Berland et.al. The Role of Trees in Urban Stormwater Management. Landscape and Urban Planning 162 (2017) 167-177.

13. Susilawati, Panduan Pelaksanaan Bangunan Pengelolaan Air Hujan Skala Rumah Tangga, Lampiran dalam Laporan Penelitian Hibah Bersaing, (2016) 